\title{
TENNESSEE WILLIAMS: ATTITUDES TOWARD LOVE AND DECAY IN BLANCHE DU BOIS AND MRS. STONE*
}

SIGRID RENAUX

This short essay ${ }^{1}$ is an attempt to deal with some seminal aspects in the personalities of Blanche Du Bois and Mis. Stone, the central characters of Tennessee Williams' play A Streetcar Named Desire ${ }^{2}$ and his novelette The Roman Spring of Mrs. Stone ${ }^{3}$, respectively. As the siory of both the play and the novelette are fairly well known - the first about Blanche, a, neurotic woman and her romantic dream world in contrast to the realism and primitivism of her brother-in-law Stanley, in a New Orleans slum; the second about an aging actress and her last ignoble love afair with a Roman gigolo - we shall start by commenting briefly on our first impressions of both works, their setting, their precedent action and plot, in order to better grasp their interrelationship with our main subject - the analysis of Blanche's and Mrs. Stone's attitudes (as older women in contrast to the other characters surrounding them) toward love and decay.

The very first impression we receive from reading Streetcar and Roman Spring is that the first is successful as a play, while the other ist not wholly successful, neither as a novelette - which it is - nor as a play - which it resembles, in structure and plot. Going back to that traditional division between plays written to be acted and plays written to be read, we could classify Streetcar in the first and Roman Spring in the second category.

I Seminário apresentado a Prof. a Dr. Winifred Kera Słavens, no curso de Teatro Americano Pós-Guerra (U.S.P., 1972).

2 WILLIAMS, T. A Streotcar Named Desire. Harmond:worth, Penguin Book, 1947. p. 113 to 226 .

3 Ibid. The Roman Spring of Mrs. Stone. New York, A New Directions Book, 1950. $148 \mathrm{pp}$.

(All references and quotations from both books will be taken from the editions above, indicated by page numbers cited in parentheses). 
Another impiession we experience is that not only the main characters but even the secondary characters in Streetcar are real people, while in Roman Spring, with the exception of Mrs. Stone, characters seem to be more clichés of gigolos and pimps than aciual types of degeneration; we realize the latter are as unreal as in a nightmare, preying on Mrs. Stone, while in Streatcar the very reality is a nightmare for Elarisha, a nightmare she does not want to accept.

Both works have, at the beginning and at the end, the same setting: Blanche arrives and leaves New Orleans in the evening for she did not accept her brutal surroundings - and Mrs. Stone is standing on a belcony in her palazzo and a stranger is looking at her; at the end, she is throwing him the keys to her residence - thus accepting degradation. In Streetcar, few changes of scene take place: a corner building, the kitchen, the bedroom and flashbacks of plantation life, marriage, and family deaths in Blanchés irregular life; in Roman Spring, Mrs. Stone's balcony, her bedroom and living room, a street in Rome, a tailor's room, plus flashbacks of her childhood, her career and her marriage.

The precendent action is important both in Streetcar as in Roman Spring, for it gives us a clue as to the personalities of Blanche and Mrs. Stone. The precedent action is always piesent in their minds: for Blanche, the plantation Belle Rêve (which represents security to her) and for Mrs. Stone, her actress career (which meant fame and an objective in life). Thus, although the visible setting is New Orleans and Rome, the invisible setting - the past - is present in the form of Belle Rêve for Blanche and New York for Mrs. Stone.Both come from this invisible setting to their new suiroundings, in a desperate search to better their lives and forget the negative aspects of their cast, but the new environment is hostile to them. They seem to wither even more, out of their native surroundings: the new setting is too brutalized for Blanche, and she succumbs by not accepting it, whereas Mrs. Stone is surrounded by decadent Italians and she willfully accepts this degradation at the end, to be free from the "drift" she feels, when alone. In a way, she is the innocent American being corrupted by old Italy, as in Henry James' novels.

The plot in Streetear centers around Blanche and in Roman Spring around Mrs. Stone: both search for balance, but they are incapable of reconciling inclination and moral obligation, and thus both suggest 
dramatic figures. They need the illusion of being loved and admired, in order to continue living, and frequently the tragic effect lies in these illusions being destroyed by those that surround them. In Blanche's case, Sianley and Mitch let her know the bitter truth about herself, while in Roman Spring, it is Paolo, the gigolo, who tells Mrs. Stone the truth. Both women feel lost and frustrated in love, which in part accounts for their nymphomania.

Their attitudes toward love becomes apparent in different ways, thus revealing complex personalities. As a start, one feels that their basic attitude toward love is wrong: Blanche, having married a homosexual when she was still very young, felt incapable of giving him help, for though she loved him deeply, she also wanied protection from him, while it was he who needed help from her. He kills himself, when she finds out about it. Having tasted too much, too soon, Blanche felt empty, and after having lost her family by death and her plantation by their debts, she has run for protection "from under one leaky roof to anoiher leaky roof" for men "don't even admit your existence unless they are making love to you. And you've got to have your existence admitted by someone, if you're going to have someone's protection" (169). Thus, from this early disillusion and the disastrous loss of Be'le Rêve, she begins her nymphomaniac career, in order to find protection and to feel young and loved. Her final affair with a seventeen-year-old boy is just another example of what in Roman Spring the newspaperwoman says to Mrs. Stone, on the balcony scene at the beginning: "Isn't it odd (...) how women of our age begin all at once to look for beauty in our male partners?" (14). But while Blanche has to se'll herself in order to receive "love", Mis. Stone buys her lovers, for she can afford it.

Mrs. Stone's marriage to an impotent, who saw in her a young mother, while she saw an adult child in him, is also basica!ly wrong. But Mrs. Stone never had any real feelings for others, just for herseif. He: vulture-like personality is just the outward aspect of her exclusiveness in love, for she wants to feel she is the only one, with no rivals, just like when she was a famous actress and always managed to remain so, even at the price of harming her partners. This rapacity and her resemblance to a prey bird is emphasized in many passages of the novel. But at the end, we see that it is the others who prey on her - Paolo, the comtessa; the stranger, while in Stroetcar, 
the "apes" take over at the end, as personified in Stanley. Blanche arouses our emotions by her complete lack of will power, for she took to drinking, wheneve: possible, while Mrs. Stone's tremendous will power only slacks at the end, when she feels the drift taking over her. She is too aware of what has happened to herself to arouse our emotions. Her great will power is also shown in the way she succeeded in her phenomenal career as an actress, at the expense of others, as mentioned.

Mrs. Stone's "Roman spring", or the discovery of physical love, on an almost animal level, reminds us also of the ancient pagan fertility rites, when a sacrifice was offered 10 a god. In Mrs. Stone's case, it seems as if in order to be granted the gif oh the physical love of a young man, she would have to pay with her dignity to appease the gods. Blanche sacrificed herself for the past she represented, but this past is no longer real to the people who surround her now. She wan's too much: physical love, plus romance and gentleness. Her values aie lost, and what she thinks she has to substitute her loss of beauty, such as beauty of the mind and tenderness of heart, are not really appreciated where she is - at her sister's home. Mrs. Stone's marriage to a "p!ump little man that looked like an Easier bunny" (14) was regarded by a fiiend as done expressly "in order to avoid copulation" (15), so her search for physical love now seems almost as a redress for something she had missed in har youth. But she simply is not capable of giving something of he:self to others and when her values are lost - beauty, career, marriage of convenience - she has nothing to replace them with, except her millions.

Blanche's and Mrs. Stone's attitudes toward decay provide us with further glimpses into their personalities. Both women are characterized by a loss of beauty and youth, although this is somenwhat relative, fo: Mrs. Stone is already fifty, while Blanche is thirty. Mrs. Stone, even made up for the stage, suddenly relaizes she cannot play Juliet anymore, whereas Blanche realizes she cannot look so fresh as sixteen, because of the hectic life she has led. So both have take.1 to fanciful dressing, to keep up the illusion of youth. But we have to remember that M:s. Stone is an American millionaire, while Blanche is poor. Thus, Mrs. Stone can afford expensive things, "now spending a great deal of money on clothes at the Roman branches of the great Farisian dressmakers. In the days of her unfaded beauty she had preferred simple clothes and a simple ring, but her taste had now shifted to gowns and jewelry that seamed inspired by the baroque façades of Bernini" (115-6). Blanche, on the other hand, wears rhinesiones, flo- 
wered prinis, a "soiled and crumpled white satin evening gown and a pair of scuffed silver slippers with brilliants set in their heels" (208).

Mrs. Stone resembles Snow White's stepmother queen, always asking the mirror if she is still the most beautiful of all; Blanche gives us the impression of imagining herself being Snow White - as her name suggests - waiting for a prince to take her home. Both women recur constantly to the mirror, although both know it tells the tiuth. Mrs. Stone is dismayed on a brilliant spring morning facing the mirror in her bedroom

with the sort of realism that still redeemed her from being a commonplace person. She was obliged to witness that her face in the mirror had nor weathered the critical period iust passed through so triumphantly as had the organs that kept her living. Her body has flown like a powerful bird through and above the entangling branches of the past few years, but her face now exhibited the record of the flight (115).

But by far the best passage illustrating the hold of a mirror over a young person comes from Paolo. Mrs. Stone has just finished dressing herself in a new costume, a dinner gown of golden taffeta covered with ivory lace, and rings and a. necklace of pearls and topaz, when Paolo bursts into her bedroom, wearing the new flannel suit she had had made specia!ly for him, by a very expensive tailor:

It was perhaps unreasonable of her to expect Paolo to be interested in her own finery (...) But Paolo's agreeable surprise was reserved for his own appearance. He rushed toward the mirror as if it were water and his clothes were on fire. Without a glance in Mrs. Stone's direction, he gazed and preened in the glass, and finding it somewhat crowded by their two reflections, he murmured Excuse me and gave her a slight push to one side. Then he turned his back to the long mirror and, looking over his shoulder, he lifted the jacket over his hips so that they both, she and he, could admire the way that the flannel adhered to ihe classic callipygian shape of his firm young behind (116-7).

Blanche, contrastingly, when she meets her sister Ste!la at the beginning of the play and the latter remarks how well she is looking, answers: "You see I still have that awful vanity about my looks even now that my looks are slipping! (She laughs nervously and glances at Siella for reassurance)" (123). One feels that she does not who!ly 
believe that her looks are slipping, and that she needs a confirmation from Stella. Later, in the outfit mentioned above, Blanche seems to be ready for a sacrifice - Stanley rapes her - and she takes a last losk into the mirror. As the stage directions indicate "Tremblingly she lifts the hand mirror for a closer inspection. She catches her breath and slams the mirror face down with such violence that the glass cracks. She moans $\theta$, little and attempts to rise" (280).

Both Blanche and Mrs. Stone also shun daylight, because it will reveal their real age to others, while the mirror reveals it. just to themselves:

In Mrs. Stone there was a certain grandeur which had replaced her former beauty. The knowledge that her beauty was lost had come upon her recently and it was still occasionally forgotten. It could be forgotten, sometimes, in the silk-filtered dusk of her bedroom where the mirrors disclosed an image in cunningly soft focus (7-8).

She knows her beauty cannot stand daylight any longer, so she recurs to dim illumination. Blanche, when she arrives in Stella's house, after they have embraced each other, says to her sister:

Now, then, let me look at you. But don't you look at me, Stella, no, no, no, not till later, not till I've bathed and rested! And turn that over-light off! Turn that offl I won't be looked at in this merciless glare! (120).

But this fligt from light cannot last forever, for neither of them. Mrs. Stone knows this, but Blanche refuses to compromise. In Roman Spring, while Mrs. S:one and Paolo sun-bathed on her terrace, she noticed that

her body turned golden, but the gold was not perfect. It contained tiny creases which would not disappear beneath the oily fingers of the masseuse who visited her daily; (...) these tinier signatures of time, little creases, stayed on her, ineffaceably" (66).

And she could not bear to look at Paolo, beside her:

He was too lustrous. The sun leapt down the air foward him like a child toward a child, and she felt ignored and excluded (as later on with the mirror, as mentioned) and usually she would reach down to cover herself, outcast, 
ashamed, in the company of such affinities as Paolo's nude flesh and the sun (66).

On another occasion Mrs. Stone is walking on the streets in Rome and receives a similar shock from daylight:

A number of times lately Mrs. Stone had gone out on the street in make-up applied almost as artfully as that she had worn on the stage, but Kioman sun!ight was not in sympathy with the deceit, and she was aware of receiving glances that were not merely critical but sometimes mocking. She had her hair tinted a darker shade, almost auburn, and she took to wearing hats with very wide brims of gossamer material that filtered the light in a flattering way, but at the back of her mind was continually the shadow of a suspicion ont yet resolved into thought that something more radical than any of these expedients must rather sooner than later be contrived to prepare her for that long crossing of time that apparently still lay before her... (115).

Blanche is characterized by her uncertain manner as well as by her white clothes as resembling a moth, an insect that cannot stand daylight either, just like her delicate beauty, as the stage directions indicate $(117)$. We also have a very revealing scene between Mitch Stanley's friend - and her when he remarks that he has never seen her in the light, nor in the afternoon. He rea!izes he has never had a real good look at her:

Mitch: Lei's furn the light on here.

Blanche (fearfully): Light? Which light? What for?

Mitch: This one with the paper thing on it (He tears the paper off the light bulb. She utters a frightened gasp). (203)

The paper lantern suggests a magical atmosphere to Blanche, for it hides the truth of her age from others. She goes on saying to Mitch:

Blanche: I don't want rea!ism.

Mitch: Naw, I guess not.

Blanche: I'll tell you wha: I want. Magic! (Mitch laughs.) Yes, yes, magic! I try to give that :o people. I misrepresent things to them. I don't tell the truth. I tell what ought to be truth. And if that is sinful, then let me be damned for 
In this manner, this speech reveals not just her age and face to Mitch, but also her bare soul to us .

The presence of the past is another means of presenting Blanche's and Mrs. Stone's attitudes toward decay. In the novelette, the past is expressed through exposition, while in the play, through the characters. Thus, in Roman Spring

Three events of great importance and impact had occurred within a year of each other in Mrs. Stone's life. They were the abandonment of her profession and her husband's death and the interval of a woman's life when the ovarian cycle is cut off. Each event had been a severe shock in itself and the three together had given her the impression that she was now leading an almost posthumous existence (42).

The word "posthumous" is relevant to the understanding not only of Mrs. Sione but also of Blanche, because the past they bring to their new environment - Belle Rêve and Mrs. Stone's career - is dead for those that surround them now. Thus, loss of beauty in Mrs. Stone is followed by her resigning her artistic career and by the death of her husband.

Blanche has had these losses, 100, although much earlier in life. But the action line is inversed in her case: disillusion in marriage, loss of the plantation, an irregular life leading to loss of beauty. Even the name Belle Rêve suggests that everything is only a dream. In the play, we know about Blanche's past through herself and through Stanley. As Blanche says to Stella,

(...) How in hell do you think all that sickness and dying was paid for? Death is expensive, Miss Stella! (...) Why, the Grim Reaper had put up his tent on our doorstep!... Stella, Bele Rêve was his headquarters! Honey - that's how it slipped through my fingers! (127)

To Stanley, Blanche explains the loss of Belle Rêve:

(...) piece by piece, our improvident grandfathers and father and uncles and brothers exchanged the land for their epic fornications - to put it plainly! (...) Till finally all that was left (...) was the house itself and about twenty acres of ground, including a graveyard, to. which now all but Stella and I have retreated (140). 
In this manner, comparing the attitudes of Mrs. Stone and Blanche toward the past, one sees that the first, already in middle age, has achieved some detachment and self-knowledge and accepts life on its new terms after Paolo leaves her. Blanche, having had those disillusions very early in life, has no detachment in analysing the events, no self-knowledge, and refuses to accept life on its new terms. Both keep the symbol of their past, nevertheless: Mrs. Stone, photographs from her actress career; Blanche, love letters in a box.

Loss of dignity is another symptom of their decay. If Mrs. Stone vas perceptive enough to see through her actress life -

with such merciless clarity, such clarity as that which had allowed her to admit to herself that her talent had been second-rate and that the pediment of her career had been youthful beauty which was now removed from her. It takes a kind of intelligence to acknowledge such a merciless truth concerning oneself and even more to survive the acknowledgement of it (114)

-- she also took dignity for granted, in the past:

In the arrogance of her beauty and her prestige in two worlds, theatrical and social, that dignity had seemed beyond the danger of compromise; but with the decline of her beauty and her removal from those spheres in which she had been a person of inviolable eminence, there was left her no protection but that of wealth: and wealth does not insure dignity (127).

Her aftraction to Paolo makes her gradually lose her dignity as a woman, for he insults her; in their final clash in her apartment. when she demands of him to tell her why he has said such awful insults to her, his fingers press on her mouth, while he hisses:

You won't listen to me (...). You won't take any warning. You are too puffed up wi'h your glory, your wealth, your magazine fashion-pictures, your wax-paper king of a husband that left you his millions. But this is a very old city. Rome is three thousand years old, and how old are you? Fifiy?

Fifty! she gasped.

It was that word that completed her undoing. Dignity she whispered to herse'f, but it was only the whis- 
pering of a word, caught up and swept away in the tempest of her fury (143).

Thus, in order to avoid the "drift" after she lost Paolo, Mrs. Stone surrenders completely to degradation, by calling the obscene young mian to her apartment. We knew from the beginning that they were going to meet. Therefore, physical decay is followed by moral decay.

Blanche loses her illusions of dignity through Stanley's crude exposure of her lies, her tricks, and her past, which culminates in his raping her, as a symbol of her complete physical and spiritual surrender to the brutish forces of tru:h surrounding her. But her exif with the doctor at the end of the play is dignified, for her slight insaneness makes her think he is a new suitor, so she leaves with dignity in contrast to Mrs. Stone's further decay.

As to both women's bearing, alihough Mis. Stone is very often compared to a prey bird, with a hawk-like expression in her eyes, while Blanche is more like a moth, in her uncertainty of manner, both resemble each other in their fright of the unknown future: Mrs. Stone, when she was a'one and thought herself unobserved, always had a "slightly frightened, anxious look" (34) in her pale blue eyes, while Blanche's fright cannot be hidden even from her sister and brotherin-law. On several occasions, there is a "frightenend look", "almost a look of panic" (192) on her face, under Stanley's insu'ting stare, and his violent gestures ande speech. Nevertheless, in spite of their inner fright, both women try to start a new life in a new environment, as mentioned. But while Mrs. Stone at the end of the story does consciously submit to degradation, in orde: to achieve this new life of security through physical love, Blanche never really accepts her degrading rea'ity, for she only believes in what she wants to believe in. As already quo'ed, "I don't tell the truth. I tell what ought to be truth" (204). And this slight madness seems to give moie dramati= depth to her than Mrs. Stone has, for Blanche wants to make tha tragedy of life - in which things are as they are - become a comedy - in which things are as they ought to be.

In this manner, we hope to have shown through the discussion of the two main characters' attitudes toward love and decay, either by pointing out thei- similarities or contrasts, some meaningful aspects of their complex personalities. At the same time, these attifudes reveal some recurrent themes in Tennessee Williams' work, for even if treated differently in each play or novel, both love and decay are present in his oeuvre, as seminal aspects th:ough which we can try 
10 explore the dark corners of man's personality, and the crises of self-recognition that we must all pass through.

\section{SUMMARY}

This study attempts to present, briefly, two important aspects in the personalities of Blanche Du Bois and Mrs. Stone, the heroines of Tennessee Williams' play A Strootcat Named Desire and his novelette The Roman Spring of Mrs. Stone. Starting with general impressions, seffing, precedent action and plot, the study then centers on both wome's attitudes towards love and decay, with their similarities and contrasts, as a means of obtaining a deeper insight into their complex perșonalities.

\section{RESUMO}

Este trabalho apresenta, de modo breve, dois aspectos importantes nas personalidades de Blanche Du Bois a Mrs. Stone, as heroinas respectivamente da peça A Strootcar Named Desire e do romance The Roman Spring of Mrs. Stone. Após mencionar impressōes gerais, cenário, ação antecedente e enredo, este trabalho sce concentra nas atitudes de ambas as mulheres em relaçăo do amor e à decadência, com seus contrastes - semelhanças, de modo a obter uma visāo mais profunda de suas personalidades complexas.

\section{BIBLIOGRAPHICAL REFERENCES}

WILLIAMS, T. The Roman Spring of Mrs. Stone. New York, A New Directions Book, 1950.. 148 pp.

Ibid. A Streatcar Named Desire. Harmondsworth, Penguin Books. 1947. p. 113 10 226. 